\title{
A CASE OF CARBON MONOXIDE POISONING.
}

\author{
By W. J. THOMPSON, M.D. Univ. Dubl., F.R.C.P.I.; \\ Physician to Jervis Street Hospital.
}

[Read in the Section of State Medicine, April 14, 1905.]

During the past 4 or 5 years quite a number of cases of carbon monoxide poisoning have occurred in Dublin owing to the mixture of water gas with the coal gas as supplied by our Gas Company, resulting, unfortunately, in the loss of life. Last Session this Section of the Royal Academy of Medicine had the privilege of hearing a most valuable and scientific paper from Professor MoWeeney on this subject, in which he minutely describes the changes he had observed in the blood, as well as other changes in different organs as found by him at post-mortem examinations.

I have had under my care in Jervis Street Hospital three cases within the past few years, and as even the larger text-books are somemhat indefinite in the description of symptoms and treatment, I thought, perhaps, the description of a case admitted under my care last year might be of some interest to the members of this Section. The case, I may say, is almost unique in how the gas poisoning was contracted, for in looking up the literature on the subject I can find no similar case recorded.

At 730 a.m. on the 12th November, 1904, F. H., a strong, healthy, able-bodied, seafaring man, aged thirty-seven years, was admitted to hospital, and I saw him shortly afterwards. The following is the history of his case we got from his companions:- He was by occupation a cook in one of the dredgers 
used at the mouth of the Liffey, and belonging to the Port and Docks Board. On the previous evening, as was his usual custom, he retired to the skipper's room about 9 o'clock, and not making his appearance at 6 o'clock next morning one of the crew knocked at the door, and getting no answer the door was burst open. The patient was found on the floor, lying on his felt side, apparently lifeless. That night the dredger was anchored some distance down the river, and although all possible haste was made it was $1 \frac{1}{2}$ hours afterwards before he was brought to the hospital in the city ambulance. It seems that on these dredgers there are usually eleven of a crew-the skipper, cook, and nine others-and at night only two of the crew, who act as watchmen, remain on board, as well as the cook. It was always the custom for the cook to retire to this room for the night. The room is dessribed as being about 17 feet long by 8 feat wide, by 7 feet high (cubical contents 952 feet), and when the door is closed there is no ventilation. At one end of the room there is a small stove in which, during the winter months, there is always a fire. We found out from the patient afterwards that when retiring that night he closed and bolted the door, and as the fire was low he put on one large block of Scotch steam coal. He remembered nothing more until he found himself in hospital.

When I saw the patient he was in a state of deep coma; the colour, not only of his face, but also of the whole body, was dusky, dark and greyish; he had well-marked short, shallow, and sterterous breathing (24 per minute); there were slight tremors of all the muscles of the body, specially of the masseters, and this tremor was rhythmical with an interval of about two minutes. The pupils were irregular, that of the right eye being slightly dilated, and that of the left eye being slightly contracted; both were insensible to very strong light. The abdomen was retracted. The surface of the body was icy cold, although the temperature taken in the rectum was $99.6^{\circ}$. The mouth was rigidly closed; the mucous membrane of the nose, as well as the inside of the ear, was in a state of anæsthesia; besides, when a catheter was passed the patient apparently did not feel it. The whole surface of the body was in the same state of anæsthesia. There was also analgesia and the sensibility to heat and cold was lost. The pulse was thready, small, easily compressible, and so quick that it was impossible to count it. The heart sounds were almo 
inaudible; that of the first sound was practically lost. The superficial reflexes, including the conjunctival, were lost, and there was well-marked rigidity of all the muscles of the bodymore particularly those of the arm. There was no urine in the bladder, although it was at least twelve hours since he had micturated. The blood when drawn off had the bright red cherry colour characteristic of carbon monoxide poisoning, and Professor MoWeeney concurs in this view.

The other two cases which came under my care were affected from inhaling the ordinary gas, as supplied to the Dublin consumers, which, as was pointed out by Professor McWeeney, is charged with carburetted water gas, sometimes to the extent of 16 per cent., whereas in ordinary coal gas (as used formerly to be supplied in Dublin) the percentage is rarely more than 6 per cent. This case illustrates how carbon monoxide poisoning may accidentally take place. Dr. Glaister, Professor of Forensic Medicine and Public Health in the University of Glasgow, in his well-known and popular text-book, describes the celebrated Snaefel case of $\mathrm{CO}$ poisoning as occurring from burning timber, in which combustion was not active because of imperfect supply of air. The probable explanation of my case which I venture to give is that there was slow combustion of the large lump of coal owing to the deficient supply of air due to the smallness of the room and the total want of ventilation. As a matter of fact, there was still a smouldering fire in the stove when the door was burst open.

It is scarcely necessary to mention that carbon monoxide poisoning is a typical example of a cumulative poison. The powerful toxic action of carbon monoxide is due to its affinity for hæmoglobin. Some authorities state that this affinity is from 150 to 200 times greater than the affinity of oxygen for hæmoglobin. When $\mathrm{CO}$ is 
inhaled it gradually displaces the $O$ of the hæmoglobin, and forms carboxyhæmoglobin-a much more stable compound than oxyhæmoglobin. In the living body carboxyhæmoglobin neither takes up nor gives off $O$, and is, therefore, incapable of acting as an $O$ carrier to the tissues. According to Haldane it is necessary in human beings that the blood be one-third saturated before the characteristic symptoms become urgent, and this explains the delay in the appearance of any serious symptoms. The combination is sufficiently intimate to resist the action of reducing agents, but it gradually yields to the action of 0 . This fact is most important, as it gives us a forcible hint in treatment, for the administration of $O$ is of paramount importance. To be of any marked service it must be used continually for a long: time. It is proved experimentally that if air or $O$ is passed for a long time through a solution of carboxyhæmoglobin the $\mathrm{CO}$ is slowly and gradually separated from the hæmoglobin, and 0 takes its place. This point was well illustrated in the first case that came under my care in hospital, and which Professor McWeeney mentions in his paper last year. The patient was three days in hospital before death, and during that time had inhaled large quantities of 0 . At the post-mortem it was found that there was no carboxyhæmoglobin, showing that the use of $O$ inhaled had doubtless affected the complete removal of the CO.

Dr. Nixon Mann, Professor of Forensic Medicine and Toxicology in Owens' College, Manchester, in his valuable and instructive text-book says that it has been stated that $\mathrm{CO}$ possess an intrinsic toxic action in addition to its power of depriving the tissues of $O$. Linossier, of Lyons, from experiments, concludes that $\mathrm{CO}$ does produce such an action: while, on the other hand, such a dis- 
tinguished authority as Haldane states that $\mathrm{CO}$ acts solely by combining with hæmoglobin, and in no other way.

The treatment adapted for this patient was the almost continuous use of $\mathrm{O}$, the prolonged carrying on of artificial respiration, hypodermic injections of digitaline, strychnine, and æther. Nutrient enemas with rectal injection of stimulants. In addition, heat was applied all round the body, and, what I consider most useful, the application of electricity along the course of the phrenic nerves and the spine. I have used saline transfusion, but, in my opinion, without any beneficial result. Copious bleeding is also important and useful.

As I have stated before, the patient's bladder was empty on admission. During his first day in hospital he passed $9 \mathrm{oz}$, on the second day $15 \mathrm{oz}$., on the third day $23 \mathrm{oz}$. The quantity passed on the fourth day was normal. No trace of sugar or albumen could be detected, although some authorities hold that sugar is present. The amount of urea was about normal per ounce. This is a contrast to my first patient, who, during the three days before death, secreted no urine, and at the post-mortem Dr. McWeeney found extreme congestion of the interlobular vessels of the kidneys.

The patient did not regain consciousness until late in the afternoon of the day of admission, and from that time he made a rapid recovery. He left hospital on the 27 th November, having been a patient for fifteen days, apparently nothing the worse of his illness. In many of the recorded cases convalescence has been very slow, and frequently some organic disease resulted.

I cannot conclude these short notes without paying a well-deserved tribute to our senior house surgeon, Dr. Loughnan, and my resident pupil, Mr. Stuart, both of 
whom so assiduously and perseveringly carried out the treatment.

Professor McWeeney stated that he had made an examination of the blood from Dr. Thompson's patient. The first specimen he examined was too small in amount for detailed examination, but presented all the appearances of the presence of CO gas combined with the hæmoglobin. At a subsequent examination no trace of CO gas was found, and the leucocyte count was also normal. Dr. McWeeney thought that Dr. Thompson deserved the greatest credit for his active and successful treatment of the case. 